\title{
The Effect of VDT Polarity and Target Size on Pupil Area
}

\author{
Masaru Miyao, Shin'ya Ishihara, Taka-aki Kondo, \\ Hisataka Sakakibara, Masashi Furuta, Katsumi Yamanaka \\ and Shin'ya Yamada
}

\author{
Department of Public Health, Nagoya University School of Medicine, Nagoya
}

\section{Introduction}

Eyestrain, neck and upper limb syndrome, along with mental stress, constitute the most frequently voiced complaints of VDT operators ${ }^{1 \sim 3}$ ). It is clear that eyestrain is affected by consistent focusing on the characters or figures on the CRT display. Thus, the size, color, flicker, resolution and other factors involved with the characters have been studied from many different standpoints ${ }^{4,5}$ ). CRT polarity has been much discussed as well. The oft-used negative displays, for example, have a low mean luminance which results in a large luminance contrast between the bright characters and dark display background. The resulting greater visual load has been pointed out in the literature ${ }^{6}$. There has yet to be any published study on the effects on pupillary area of factors such as polarity or target-size. In the present study, we compared positive and negative CRT display conditions, varying the size of the target in the center of the screen, to determine the effect on the pupil area.

\section{Materials and Methods}

The subjects were 12 healthy female volunteers aged 20-21 years, with overall corrected visual acuity of more than $20 / 20$ and no past history of ophthalmological diseases. The lab was windowless with fluorescent lighting arranged so as to provide constant illuminance of $170 \mathrm{~lx}$ on the horizontal surface and $50 \mathrm{~lx}$ on the vertical surface. There was little reflected glare on the screen. The test period was from 11:00 am to 4:00 pm. An NEC Model PC8853n color display (14") was used as the CRT. Subjects used a chin rest secured at a point from which their eyes would be $50 \mathrm{~cm}$ away from the display. The eyes of subjects were exposed to infrared rays originating from a lamp positioned at an angle in front and passing through an infrared filter. The subjects' right eyes were photographed from the front with an infrared camera.

For the test loading, we employed the respective polarity of the positive and negative CRT displays, as subjects gazed at the target, a circle having one of two different sizes painted in the center of the display, for $10 \mathrm{~s}$. With reference to target size, circles $10 \mathrm{~mm}$ in diameter and $31.6 \mathrm{~mm}$ in diameter were used. In the case of negative polarity, a white target was made to appear suddenly on the dark background. A dark target was presented on the white background with positive polarity.

As shown in Figure 1, the pupillary area of the right eye of each subject was measured for every 10 -second load using infrared videopupillography (Hamamatsu Photonics Inc.). The right eye was shown on a TV monitor with the pupil displayed in white; the high contrast condition made it stand out against all other portions, which were darkened. The entire pupil was observed on the display monitor, and the size (pupillary area) could be measured by the number of phosphor elements. The measured area was sampled 40 times per second, entered into a personal computer as a digital signal

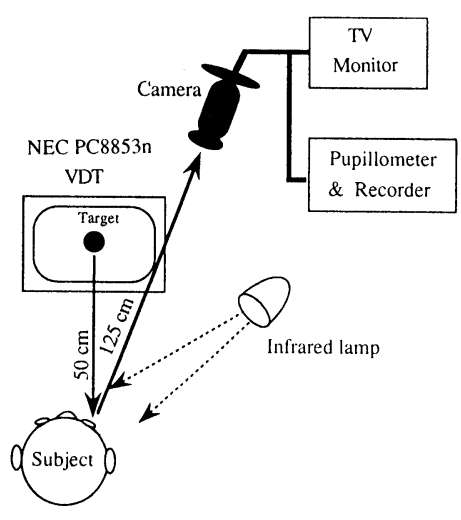

Figure 1 Experimental layout 
and recorded on a floppy disk. For calibration of the pupillary area, a precise black circle with a diameter of $4.62 \mathrm{~mm}$ was measured, and used to calculate the actual pupillary area. In order to evaluate the change of pupil size, average values of pupil areas were calculated for five seconds (between the first 5 and 10 seconds).

\section{Results}

Figure 2 gives the mean plots of the data for 10 seconds in the 12 subjects under the various conditions studied. Average values of initial pupil areas were approximately $32 \mathrm{~mm}^{2}(6.4 \mathrm{~mm}$ in diameter) for the negative polarity display, and approximately $10 \mathrm{~mm}^{2}(3.6 \mathrm{~mm}$ in diameter) for the positive polarity display. The pupillary areas at the starting points of the respective loads show rapid changes because the target was displayed suddenly. The pupil areas for the negative display dilated obviously because of a low mean luminance. In the case of the positive polarity, pupil areas showed smaller changes or weaker constrictions.

Figure 3 shows the results of Kruskal-Wallis and Scheffe's tests. On the negative screen with a target $31.6 \mathrm{~mm}$ in diameter, the pupil size was significantly dilated. With negative polarity, the larger

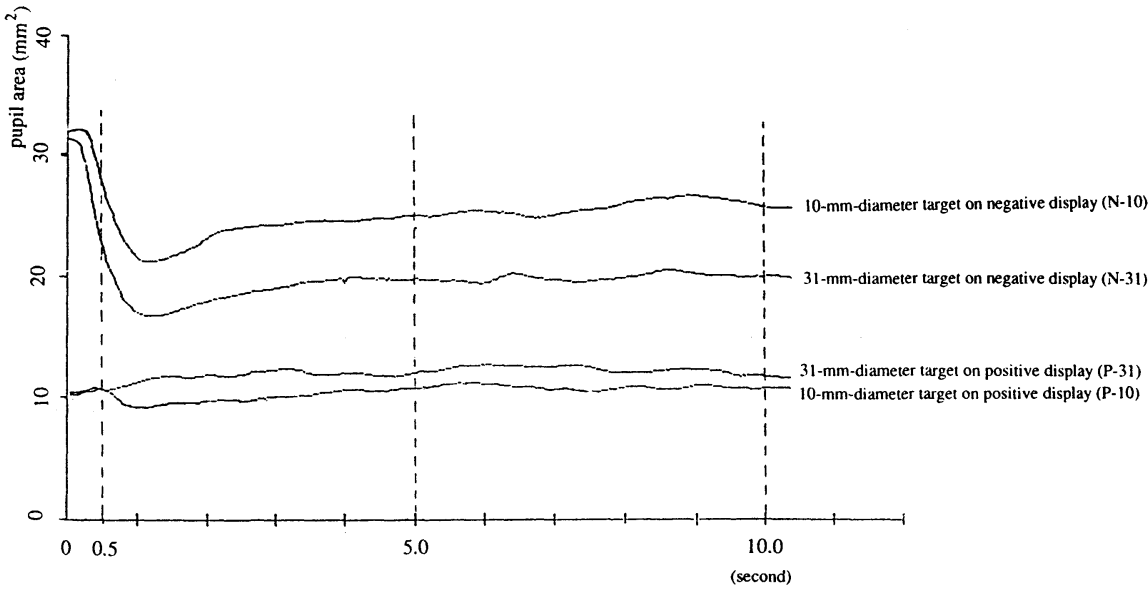

Figure 2 Changes of mean values of pupil area in 12 subjects for the various conditions

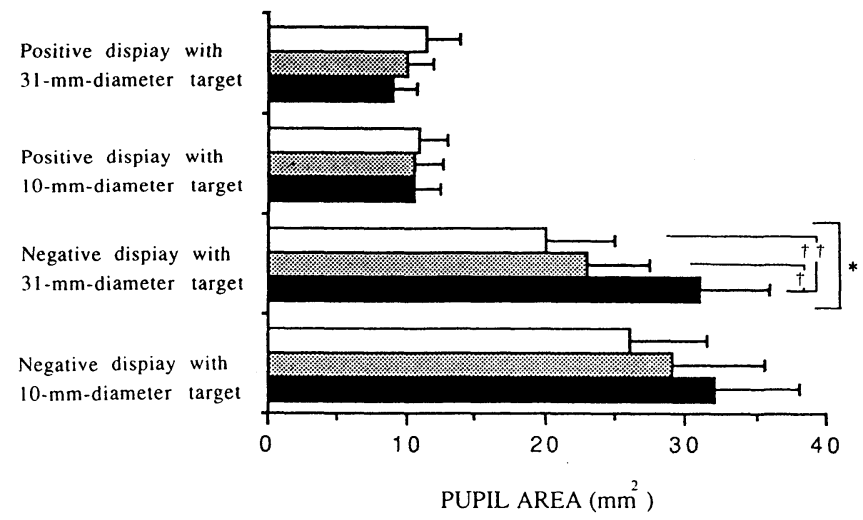

Figure 3 Changes in mean values of pupil area in 12 subjects under various conditions (mean $\pm 1 \mathrm{~S}$. D.)

* $\quad: \mathrm{p}<0.001$, Kruskal-Wallis test

$\dagger \quad: p<0.05$, Scheffe's test

$\dagger+: p<0.01$, Scheffe's test 
the target was, the more markedly the pupil constricted. However, a target on the positive display hardly changed the pupil area.

Analysis of variance for absolute differences between initial pupil area and backward values was conducted. The values of the pupil area at 0.5 second and the average pupil area for five seconds (between the first 5 and 10 seconds) were used with the initial values in Tables 1 and 2 , respectively. A larger pupil was observed with a target $10 \mathrm{~mm}$ in diameter on a dark background, while a smaller pupil appeareả when the $10 \mathrm{~mm}$ target was displayed against a white background. Similarly, a larger pupil was observed with the target $31.6 \mathrm{~mm}$ in diameter on the dark background, while a smaller pupil appeared when the $31.6 \mathrm{~mm}$ diameter target was displayed against the white background. The pupil area in the negative displays was significantly larger than in the positive displays $(p<0.001)$. Analysis of variance for differences between initial values of pupil area and 0.5 second values revealed that polarity, target size and interaction influenced the change in pupil area significantly. In the analysis of variance, differences between initial values of pupil area and mean values for five seconds (between the first 5 and 10 seconds) were significantly affected by polarity and target size. In this analysis, the interaction was pooled into the residual because it was not significant for the pupil change.

Table 1 Analysis of variance for differences between initial values of pupil area and $0.5 \mathrm{~s}$ values.

\begin{tabular}{crrrrc}
\hline Sources of variation & \multicolumn{1}{c}{ S S } & D F & \multicolumn{1}{c}{ M S } & \multicolumn{1}{c}{ F } & Significance \\
\hline Polarity & 337.13 & 1 & 337.13 & 95.07 & 0.0001 \\
Target size & 74.83 & 1 & 74.83 & 21.10 & 0.0001 \\
Interaction & 53.28 & 1 & 53.28 & 15.02 & 0.001 \\
\hline Residual & 156.04 & 44 & 3.55 & & \\
Total & 621.27 & 47 & 13.22 & & \\
\hline
\end{tabular}

Table 2 Analysis of variance for differences between initial values of pupil area and mean values for five seconds (between first 5 and 10 seconds.)

\begin{tabular}{cccccc}
\hline Sources of variation & \multicolumn{1}{c}{ S S } & D F & M S & \multicolumn{1}{c}{ F } & Significance \\
\hline Polarity & 657.79 & 1 & 657.79 & 48.02 & 0.0001 \\
Target size & 116.28 & 1 & 116.28 & 8.49 & 0.01 \\
\hline Residual* & 616.37 & 45 & 13.70 & & \\
Total & 1390.44 & 47 & 29.58 & & \\
\hline
\end{tabular}

*Interaction is pooled.

\section{Discussion}

The results indicate that the factor with the greatest effects on pupillary size was target luminance. The relationship between this target luminance and pupil diameter was analyzed by Reeves ${ }^{7)}$ and Crawf ord ${ }^{8}$. According to Reeves, when a change of light intensity by about $10^{9}$ times was made, the pupil diameter was found to change from $8 \mathrm{~mm}$ to $2 \mathrm{~mm}$. Crawford reported that, when target luminance changed approximately $10^{6}$ times, the pupil diameter changed from about $5.7 \mathrm{~mm}$ to about $2 \mathrm{~mm}$. Campbell ${ }^{9)}$, using a synthetic pupil, varied the target luminance in order to obtain the pupil diameter allowing the maximum visual acuity. His results virtually agreed with the natural pupil diameter measurements of Reeves and Crawford. In the pupil reflex there is also a near reflex in addition to the aforementioned light reflex. When one looks at a target near at hand, the pupil contracts together with the convergence movement of both eyes and the ensuing accommodation. In the present experiment, the visual distance was constant at $50 \mathrm{~cm}$. At this distance, the convergence reflex is not taken to be definite. There is also a diurnal variation in the pupillary area. Our present experiment was run between the hours of 11:00 am and 4:00 pm, so this time zone was fairly stable.

There are few studies on the relationship between VDT and pupillary area. Zwahlen ${ }^{10)}$ had subjects 
focus 96 consecutive times on 4 different locations (screen, keyboard, document, and wall) of a VDT workstation, in order to measure successive changes in pupil diameter. As a result, in young persons (aged 19-22), the pupil diameter became slightly larger, depending on the target luminance, whereas in older persons (61-66 years of age) the pupil diameter obviously grew smaller, with fewer changes recorded.

The American National Standards Institute ${ }^{4)}$ indicated that in workplaces with visual display terminals, illuminance in the range of $200 \mathrm{~lx}$ to $500 \mathrm{~lx}$, measured on the work area of the work surface, was normally sufficient. But a higher illuminance (approximately $500 \mathrm{~lx}-1,000 \mathrm{~lx}$ ) is usual in a Japanese office with VDTs. In the present experiment, we provided constant illuminance of $170 \mathrm{~lx}$ on the horizontal surface and $50 \mathrm{~lx}$ on the vertical surface. These illuminance levels were very low .

We may consider that the pupillary size in this experiment was somewhat overestimated because of the dark illuminance level when compared with the actual of fice environment.

The results of our study indicated that screen polarity had a marked influence on pupillary area. A difference in pupil area resulted from a difference in target size. With a positive display, the pupil invariably contracted. The white area (background) luminance was $38.0 \mathrm{~cd} / \mathrm{m}^{2}$ against a dark area (target in the center of the display) luminance of $1.2 \mathrm{~cd} / \mathrm{m}^{2}$, so it was not surprising that a light reflex occurred when focusing on a positive VDT display. But it is important to note that, irrespective of target luminance, a difference in pupillary area resulted from the total luminance of the display. Table 1 shows that the interaction between polarity and target size significantly influenced the differences between the initial values of the pupil area and 0.5 second values. From Figure 2 , it is obvious that the pupil area values for negative displays had rapid changes at around 0.5 second, whereas pupil areas for positive displays showed little change, indicating that the interaction was significant.

Moses ${ }^{11)}$ performed a geometric estimate of depth of field. According to him, when actual accommodation is at $1 \mathrm{~m}$ (1D), if the pupil diameter is $2 \mathrm{~mm}$ the target should be distinct even at 0.94-1.06 $\mathrm{m}$; on the other hand, when the pupil diameter is $4 \mathrm{~mm}$, unless the target is at $0.97-1.03 \mathrm{~m}$, it may not be seen clearly. In other words, as the pupil expands the depth of field becomes shallower, and accommodation must in fact be more rigorous. In the light of the findings of Moses, where the pupillary area increased in terms of a negative display, the depth of focus obviously becomes shallower. Hence, unless accommodation is exact, reading would presumably become impossible. Conversely, when the pupillary area contracts with a positive display, the depth of focus becomes greater, presumably making the load on accommodation much less, though this should be tested empirically .

\section{Conclusion}

Negative and positive VDT screen conditions were compared with respect to pupil area. Twelve healthy female volunteers were used as subjects. A white VDT screen with negative or positive polarity was used to gaze at the target. Two targets, $10 \mathrm{~mm}$ in diameter, and $31.6 \mathrm{~mm}$ in diameter were used. The pupil area was measured for every 10 -second load using inf rared videopupillography. The initial values of pupil area, the values at 0.5 second and average pupil areas for five seconds (between the first 5 and 10 seconds) were calculated. The results showed that the pupil area for the negative displays was significantly larger than for the positive displays. With negative polarity, the larger the target was, the more markedly the pupil constricted. When the VDT used had positive polarity, the pupil dilated in proportion to target size. The results indicate that screen polarity has a marked influence on pupil area, and that a difference in pupil area results from a difference in target size.

\section{Acknowledgements}

The authors wish to thank Mr. Hirokazu Iguchi, Toyota Central Res. and Develop. Labs., Inc., for his technical assistance. Thanks are also due to Professor Hisao Ishigaki, Aichi institute of Technology, for his valuable remarks. 


\section{References}

1) Bennet, J., Case, D., Sandelin, J. and Smith, M.: Visual Display Terminals, Prentice-Hall, Englewood Cliffs NJ (1984).

2 ) Grandjean, E.: Ergonomics and Health in Modern Offices, Taylor \& Francis, London (1984).

3 ) Scalet, E.: VDT Health and Safety, Ergosyst Assoc., Lawrence, KA (1987).

4 ) American National Standards Institute (ANSI): ANS for Human Factors Engineering of VDT Workstations, The Human Factors Society, Santa Monica, CA (1988).

5 ) Miyao, M., Hacizalihzade, S.S., Allen, J.S. and Stark, L.W.: Effects of VDT resolution on visual fatigue and readability: an eye movement approach, Ergonomics, 32, 603-614 (1989).

6 ) Bauer, D. and Cavonius, C.R.: Improving the legibility of visual display units through contrast reversal, In "Ergonomic Aspects of Visual Display Terminals" (Editor: E. Grandjean and E. Vigliani), p.137-142, Taylor \& Francis, London (1980).

7 ) Reeves, P.: Rate of pupillary dilation and contraction, Psychol. Rev ., 25, 330-340 (1918).

8 ) Crawford, B.H.: The dependence of pupil size upon external light stimulus under static and variable conditions, Proc. Roy. Soc., 121B, 376-395 (1936).

9 ) Campbell, F.W. and Gregory, A.H.: Effects of size of pupil on visual acuity, Nature, 187, 1121-1123 (1960).

10) Zwahlen, H.T.: Pupillary responses when viewing designated locations in a VDT workstation, In "Ergonomics and Health in Modern Offices" (Editor: E. Grandjean), p.339-345, Taylor \& Francis, London (1984).

11) Moses, R.A.: Accommodation, In "Adler's Physiology of the Eye" (Editor: R.A. Moses), p. 298-319, The C.V. Mosby Company, Saint Louis (1975).

(Received September 24, 1991/Accepted December 24, 1991)

\section{VDTの極性および視標の大きさが朣孔面積に与える影響}

宮尾克, 石原伸哉, 近 藤 高 明,
榊原 久 孝, 古田真司, 山 中 克 己,
山田信也

名古屋大学医学部公衆衛生学教室

VDT画面を注視する際に瞳孔面積がぞのように変化するかについて，陰画表示と陽画表示とを用いて比較検討され た。12人の健康女子学生を被検者にして，白色の画面の中央部におかれた円形の視標を注視するように指示した。視標 の大きさは 2 種類設定し, 直径 $10 \mathrm{~mm}$ と $31.6 \mathrm{~mm}$ とした。瞳孔面積は赤外線瞳孔面積計で10秒間ずつ測定され，初期值， 0.5 秒值, および 5 秒から 10 秒むでの 5 秒間の平均值が, 計測され解析に用いられた。

実験の結果, 陰画表示の場合に, 陽画表示に比べて有意に瞳孔面積が大きかった。陰画表示の場合には視標の大きさ が大きいほど，著明に縮曈した。陽画表示のとさには，視標が大きいほど散瞳した。極性と視標の大きさの 2 变数(と もに 2 水準)による 2 元配置の分散分析によって，特性值である瞳孔面積の变化は，いずれの変数にたいしても有意で 西った。これらの結果から, VDTの画面の極性の相違と，画面上の視標の大きさの相違によって瞳孔面積が変化する ことが明らかとなった。 